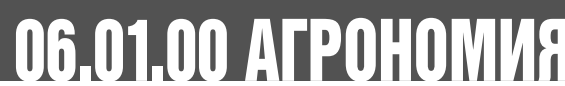

\section{ПРОДУКТИВНОСТЬ СОРТИМЕНТА КОРМОВОГО СОРГО В ЗАВИСИМОСТИ ОТ ФОНА МИНЕРАЛЬНОГО ПИТАНИЯ}

Бельченко Сергей Александрович, доктор сельскохозяйственных наук, профессор кафедры "Агрономия, селекция и семеноводство»

Дронов Александр Викторович, доктор сельскохозяйственных наук, профессор кафедры «Аحрономия, селекция и семеноводство»

Шаповалов Виктор Федорович, доктор сельскохозяйственных наук, профессор кафедры «Агрохимия, почвоведение и экология»

ФГБОУ ВО БрянСКИЙ ГАУ

243365, Брянская область, Выгоничский район, с. Кокино, ул. Советская, 2а; тел./факс: +7(48341) 24-721; e-mail: cit@bgsha.com

Ключевые слова: кормовое сорго, гибриды, минеральное питание, продуктивность, питательные вещества.

В результате проведенных полевых опытов на агросерых лесных почвах Брянской области нами выявлено, что минеральные удобрения (нитрофоска, борофоска, аммиачная селитра) оказали существенное влияние на рост, развитие и продуктивность сорговых культур, содержание питательных веществ и устойчивость к абиотическим факторам. Продуктивными оказались генотипы сорго сахарного $F_{1}$ Порумбень 4 и Порумбень 5 селекции Института кукурузы и сорго (Республика Молдова) - 14,4-15,2 m/га сухого вещества. Урожайность сорго-суданковых гибридов селекции ВнИи сорго и сои «Славянское поле» составила 8, 4-9,8 $\mathrm{m} / 2 \mathrm{a}$ СВ при одноукосном использовании (силосный вариант). В структуре урожая сорго сахарного (\%) в среднем доля листьев составила 51,3, стеблей - 41,7, метелок - 7,0 и в структуре сухой массы сорго-суданковых гибридов - 42,1-56,2 \%, 42,4-50,0 \%, метелок 6,4-7,9 \% соответственно. На варианте применения борофоски отмечалось высокое содержание сахаров, особенно у растений сочностебельного сорго-суданкового гибрида Славянское поле $15 F_{1}(14,5 \%)$. При азотных подкормках проявилась общая тенденция снижения концентрации сахаров в соке стеблей, фосфора и калия изучаемых гибридов сорго и кукурузы. Содержание питательных веществ изменялось по фазам роста и развития и в зависимости от фона минерального питания. В фазу стеблевания - выхода в трубку кормовая масса характеризовалась высоким содержанием сырого протеина (14,4%), более низким - сырой клетчатки и БЭВ, особенно на вариантах, удобренных азотом. В фразу молочно-восковой спелости зерна изучаемых культур содержание сырого протеина в кормах снижалось до 10,2-10,9 \%, а сырой клетчатки повышалось до 32 \%. Внесение минеральных удобрений незначительно влияло на долю зольных элементов, сырой клетчатки и БЭВ, но способствовало повышению содержания сырого протеина и увеличению урожайности надземной массы, которую можно использовать для заготовки высококачественного зелёного корма, сенажа, силоса.

\section{Введение}

Сорговые культуры (сорта и гибриды) благодаря ряду своих биологических особенностей, хорошей кустистости, быстрому послеукосному отрастанию характеризуются высокой экологической пластичностью, продуктивностью, кормовыми достоинствами, универсальностью использования. В группу кормового сорго включают сорго зерновое, сахарное, сорго-суданковые гибриды, суданскую траву, судзерн (суданка зерновая).

Учёными, селекционерами и исследовате- 
лями Дона, Поволжья, Краснодарского и Ставропольского края, республик ближнего зарубежья (Беларусь, Молдова) ведется большая и результативная работу по селекции, семеноводству, разработке современных агротехнологий сорговых культур на продовольственные, кормовые, технические и другие цели $[1,2,3,4,5,6]$.

В настоящее время хозяйства Брянской области успешно используют в полевом кормопроизводстве разработки учёных Брянского ГАУ по внедрению сорговых культур в регионе [7, 8, 9]. И в этой связи исследования особенностей продукционного процесса посевов кормового сорго в зависимости от условий минерального питания положены в основу данной работы.

Целью наших исследований являлось изучение влияния различного уровня минерального питания на продуктивность сортимента сорговых кормовых культур в условиях серых лесных почв Брянского Ополья. Основная задача заключалась в оценке эффективности минеральных удобрений и их влияния на урожайность, структуру урожая и качество кормовой массы из сорго зернового, сахарного, сорго-суданковых гибридов.

\section{Объекты и методы исследований}

Полевые эксперименты проводились в 2014-2016 гг. на стационаре опытного поля Брянского ГАУ. Почва агросерая лесная среднесуглинистая по гранулометрическому составу. Мощность гумусового горизонта - 20-50 cм, содержание гумуса - 3,8-4,0 \% (по Тюрину). Реакция почвенного раствора на уровне $\mathrm{pH} 5,6-5,8$; гидролитическая кислотность (Нг) - 2,63 мг-экв. на 100 г почвы.
Объектами исследований были перспективные гибриды сорговых культур селекции ВНИИ сорго и сои «Славянское поле» (Ростовская область): сорго зерновое Славянское поле 120, сорго сахарное Славянское приусадебное, сорго-суданковые гибриды Славянское поле 15, Славянское поле 18, Приусадебный и гибриды сорго сахарного Порумбень 4, Порумбень 5 селекции Института кукурузы и сорго «Порумбень» (Республика Молдова). Предшественниками по годам изучения являлись соя, однолетние травы, озимая тритикале. Агротехника опытов общепринятая для кормовых и силосных культур в регионе.

Изучение влияния минерального питания на продуктивность сортимента сорговых культур проводили на посевах зернового, сахарного сорго, сорго-суданковых гибридов и раннеспелого гибрида кукурузы Бемо 182 СВ (ФАО 200) в качестве контроля. Норму минеральных удобрений по вариантам опыта в форме нитрофоски - фон $1\left(\mathrm{~N}_{60} \mathrm{P}_{60} \mathrm{~K}_{60}\right)$ и борофоски - фон $2\left(\mathrm{P}_{60} \mathrm{~K}_{60}\right)$ вносили в предпосевную культивацию и азотные удобрения в виде аммиачной селитры (подкормка): дозы - $\mathrm{N}_{30}, \mathrm{~N}_{60}$ и $\mathrm{N}_{90}$ в фазу начала кущения на данных фонах. Каждый генотип высевали сеялкой CH-16 по 4 ряда с шириной междурядий $60 \mathrm{~cm}$, длина делянки - 70 м, повторность опыта 4-кратная, площадь учётной делянки - $10 \mathrm{~m}^{2}$, размещение вариантов систематическое.

Учёт урожая надземной массы проводился укосным методом поделяночно путем взвешивания - в фазе выметывания (кормовой вариант, двухукосное использование) и молочно-восковой спелости зерна (сенажно-силосный

Таблица 1

Метеорологические условия за вегетационный период исследований

\begin{tabular}{|c|c|c|c|c|c|c|c|}
\hline \multirow[b]{2}{*}{ Показатель } & \multirow[b]{2}{*}{ Год } & \multicolumn{5}{|c|}{ Месяц } & \multirow{2}{*}{$\begin{array}{c}\text { За } \\
\text { вегетационный } \\
\text { период }\end{array}$} \\
\hline & & май & июнь & июль & август & сентябрь & \\
\hline \multirow{4}{*}{$\begin{array}{c}\text { Сумма осадков, } \\
\text { мм }\end{array}$} & 2014 & 92,1 & 25,1 & 61,6 & 28,2 & 36,1 & 243,1 \\
\hline & 2015 & 66,7 & 121,3 & 90,9 & 5,6 & 87,8 & 372,3 \\
\hline & 2016 & 26,6 & 67,8 & 95,0 & 20,2 & 38,4 & 248,0 \\
\hline & $\begin{array}{c}\text { Среднее } \\
\text { многолетнее }\end{array}$ & 55,0 & 65,0 & 82,0 & 64,0 & 46,0 & 312,0 \\
\hline \multirow{4}{*}{$\begin{array}{c}\text { Температура } \\
\text { воздуха, } \text { C }^{\circ}\end{array}$} & 2014 & 16,4 & 16,4 & 21,0 & 19,9 & 12,7 & 17,3 \\
\hline & 2015 & 14,6 & 18,2 & 18,9 & 19,3 & 15,1 & 17,2 \\
\hline & 2016 & 15,3 & 18,6 & 20,7 & 19,6 & 12,4 & 17,3 \\
\hline & $\begin{array}{c}\text { Среднее } \\
\text { многолетнее }\end{array}$ & 12,5 & 16,6 & 18,4 & 17,1 & 11,4 & 15,2 \\
\hline
\end{tabular}


Таблица 2

Продуктивность и структура урожая надземной массы кормового сорго при одноукосном использовании (2014-2016 гг.)

\begin{tabular}{|l|c|c|c|c|}
\hline Культура, гибрид & $\begin{array}{c}\text { Продуктивность, (сухое } \\
\text { вещество) т/га }\end{array}$ & Листья & Стебли & Метелки \\
\hline $\begin{array}{l}\text { Сахарное сорго Славянское } \\
\text { приусадебное } F_{1}\end{array}$ & 12,4 & 51,3 & 41,7 & 7,0 \\
\hline F Порумбень 4 $_{1}$ & 14,4 & 47,3 & 52,7 & - \\
\hline F Порумбень 5 $_{\text {Сорго-суданковые гибриды }}$ & 15,2 & 45,3 & 54,7 & - \\
\hline Славянское поле 15 $F_{1}$ & 9,8 & 42,1 & 50,0 & 7,9 \\
\hline Славянское поле 18 $F_{1}$ & 8,7 & 50,1 & 42,4 & 7,5 \\
\hline Приусадебный $F_{1}$ & 8,4 & 50,2 & 43,4 & 6,4 \\
\hline НСР (по годам) & $0,65-0,94$ & & & \\
\hline
\end{tabular}

вариант). Определение водорастворимых сахаров в соке стеблей проводили на рефрактометре RL-3. Расчет питательной и энергетической ценности сухого вещества зелёной массы кормового сорго проводили на основании данных биохимического анализа, выполненного в Центре коллективного пользования приборным и научным оборудованием Брянского ГАУ $[10,11]$. Статистическую обработку данных - методом дисперсионного анализа по Б.А. Доспехову [12] с использованием пакета прикладных программ STRAZ и Stadia на персональном компьютере.

За период исследований по многолетним данным метеостанции Брянского ГАУ погодные условия отличались различным характером по количеству осадков и среднесуточной температурой воздуха (табл. 1).

Так, вегетационный период 2014 года характеризовался повышенным температурным режимом (сумма температур свыше $10^{\circ} \mathrm{C}$ составила $2460{ }^{\circ} \mathrm{C}$ ) и дефицитом осадков, особенно в июне, когда выпало 52 \% от нормы. В 2015 году температурный и режим влагообеспеченности оказались благоприятными для онтогенеза и возделывания кормового сорго. В июне-июле 2016 года средняя температура воздуха составила $18,6-20,7^{\circ} \mathrm{C}$ и была выше среднемноголетних значений. В целом можно сказать: за период проведения исследований метеорологические условия характеризовались высокой увлажненностью и избыточностью осадков (ГТК выше 1,3), следовательно, в регионе именно температурные условия выступают как лимитирующий фактор культуры сорго.

\section{Результаты исследований}

Нашими исследованиями выявлено, что минеральные удобрения оказали существенное влияние на рост, развитие и продуктивность сор- говых растений, содержание питательных веществ, устойчивость к абиотическим факторам. Так, заметно сказалось внесение минеральных удобрений, и особенно азотных, на продолжительность вегетационного периода при формировании надземной массы и зерна сорго. В контрольном варианте (без удобрений) растения имели бледно-желтую окраску листьев и стеблей и их вегетационный период (всходы - начало полной спелости зерна) составил 126-130 суток. На делянках с внесением полного минерального удобрения - фон нитрофоска $\left(\mathrm{N}_{60} \mathrm{P}_{60} \mathrm{~K}_{60}\right)$ и азотные удобрения в подкормке - растения имели темно-зеленую окраску, и основные фазы развития проходили более длительное время, особенно кущение - выход в трубку. На удобренных вариантах этот период был на 8-12 суток продолжительнее, чем в вариантах без внесения удобрений.

В среднем за 3 года на фоне применения нитрофоски и азотных подкормок во время вегетации наиболее продуктивными оказались гибриды сорго сахарного Порумбень 4 и Порумбень 5 (14,4-15,2 т/га сухого вещества). Посевы сорго сахарного Славянское приусадебное $\mathrm{F}_{1}$ сформировали урожайность в среднем 12,4 т/ га сухого вещества, при этом в структуре урожая доля листьев составила 51,3 \%, стеблей - 41,7\%, метелок - 7,0 \%. Урожайность сухой массы сорго-суданковых гибридов была в пределах 8,4-9,8 т/га, и в структуре урожая на долю листьев приходилось 42,1-50,2 \%, стеблей - 42,4-50,0 \%, метелок - 6,4-7,9 \% (табл. 2).

Экспериментальные данные таблицы 3 позволяют установить, что большинство изученных гибридов кормового сорго в агроклиматических условиях Брянской области более полно реализуют свою биологическую продуктивность 
Таблица 3

Сравнительная оценка направлений использования сорго сахарного по выходу сырого протеина в зависимости от фона минерального питания (2015-2016 гг.)

\begin{tabular}{|c|c|c|c|c|}
\hline \multirow[b]{2}{*}{$\begin{array}{l}\text { Культура, } \\
\text { гибрид }\end{array}$} & \multirow[b]{2}{*}{$\begin{array}{c}\text { Фон минерального } \\
\text { питания }\end{array}$} & \multicolumn{2}{|c|}{ Сбор сырого протеина, т/га } & \multirow[b]{2}{*}{$\begin{array}{c}\text { Кормовое в \% к } \\
\text { силосному }\end{array}$} \\
\hline & & силосное & $\begin{array}{c}\text { кормовое } \\
\text { (всумме за2 } у \text { укоса) }\end{array}$ & \\
\hline \multirow{5}{*}{$\frac{\text { Сорго сахарное }}{\text { Порумбень } 4 \mathrm{~F}_{1}}$} & Без удобрений (К) & 1,49 & 1,49 & 100,0 \\
\hline & $\mathrm{N}_{60} \mathrm{P}_{60} \mathrm{~K}_{60}-$ фон 1 & 1,75 & 2,02 & 115,4 \\
\hline & $\mathrm{P}_{60} \mathrm{~K}_{60}-\phi \mathrm{OH} 2$ & 1,67 & 1,92 & 115,0 \\
\hline & $\mathrm{N}_{60} \mathrm{P}_{60} \mathrm{~K}_{60}+\mathrm{N}_{60}$ & 1,88 & 1,97 & 104,8 \\
\hline & $\mathrm{P}_{60} \mathrm{~K}_{60}+\mathrm{N}_{60}$ & 2,01 & 2,10 & 104,5 \\
\hline \multirow{5}{*}{$\begin{array}{c}\text { Сорго сахарное } \\
\text { Славянское } \\
\text { приусадебное } F_{1}\end{array}$} & Без удобрений (К) & 1,48 & 1,48 & 100,0 \\
\hline & $\mathrm{N}_{60} \mathrm{P}_{60} \mathrm{~K}_{60}-$ фон 1 & 1,93 & 2,23 & 115,5 \\
\hline & $\mathrm{P}_{60} \mathrm{~K}_{60}-$ фон 2 & 1,84 & 2,31 & 125,5 \\
\hline & $\mathrm{N}_{60} \mathrm{P}_{60} \mathrm{~K}_{60}+\mathrm{N}_{60}$ & 2,13 & 2,22 & 104,2 \\
\hline & $\mathrm{P}_{60} \mathrm{~K}_{60}+\mathrm{N}_{60}$ & 2,33 & 2,33 & 100,0 \\
\hline \multirow{5}{*}{$\begin{array}{c}\text { Сорго-суданковый } \\
\frac{\text { гибрид }}{\text { Славянское поле }} \\
15 \mathrm{~F}_{1}\end{array}$} & Без удобрений (К) & 1,16 & 1,18 & 101,7 \\
\hline & $\mathrm{N}_{60} \mathrm{P}_{60} \mathrm{~K}_{60}-$ фон 1 & 1,27 & 1,49 & 117,3 \\
\hline & $\mathrm{P}_{60} \mathrm{~K}_{60}-\phi \mathrm{OH} 2$ & 1,60 & 1,65 & 103,1 \\
\hline & $\mathrm{N}_{60} \mathrm{P}_{60} \mathrm{~K}_{60}+\mathrm{N}_{60}$ & 1,59 & 1,69 & 106,3 \\
\hline & $\mathrm{P}_{60} \mathrm{~K}_{60}+\mathrm{N}_{60}$ & 1,62 & 1,66 & 102,5 \\
\hline
\end{tabular}

Таблица 4

Влияние минеральных удобрений на содержание водорастворимых сахаров в соке стеблей, \% (2016 г.)

\begin{tabular}{|l|c|c|c|c|}
\hline \multirow{2}{*}{$\begin{array}{c}\text { Фон минерального } \\
\text { питания }\end{array}$} & $\begin{array}{c}\text { Кукуруза } \\
\text { Бемо } 182 \mathrm{CB}\end{array}$ & $\begin{array}{c}\text { Сорго зерновое } \\
\text { Славянское поле } 120 \\
\mathrm{~F}_{1}\end{array}$ & $\begin{array}{c}\text { Сорго сахарное } \\
\text { Славянское } \\
\text { приусадебное } \mathrm{F}_{1}\end{array}$ & $\begin{array}{c}\text { Сорго-суданковый } \\
\text { гибрид Славянское } \\
\text { поле } 15 \mathrm{~F}_{1}\end{array}$ \\
\hline Без удобрений (K) & 7,1 & 13,9 & 11,9 & 13,0 \\
\hline $\begin{array}{l}\mathrm{P}_{60} \mathrm{~K}_{60}-\text { фон - } \\
\text { борофоска }\end{array}$ & 8,4 & 14,1 & 13,0 & 14,5 \\
\hline Фон $+\mathrm{N}_{30}$ & 8,0 & 13,4 & 12,8 & 14,2 \\
\hline Фон $+\mathrm{N}_{60}$ & 6,0 & 12,5 & 12,1 & 13,9 \\
\hline Фон $+\mathrm{N}_{90}$ & 5,9 & 12,0 & 11,8 & 13,2 \\
\hline
\end{tabular}

при «кормовом» варианте использования (двухукосный вариант). Так, посевы гибрида сорго сахарного Славянское приусадебное $\mathrm{F}_{1}$ в кормовом варианте по выходу с урожаем сырого протеина в сухой надземной массе на 15,5 \% (фон 1) и на 25,5 \% (фон 2) формировали больше, чем при силосном варианте. Гибрид сорго сахарного Порумбень $4 \mathrm{~F}_{1}$ одинаково реализовал свой потенциал в «силосном» и «кормовом» использовании (115,0 и 115,4 \% соответственно). В отношении сорго-суданковых гибридов следует отметить, что в кормовом варианте на фоне 1 была обеспечена большая продуктивность по выходу сухого вещества, а по сбору сырого протеина гибриды Славянское поле 15 и Славянское поле 18 практически не отличались по вариантам хозяйственного использования.

Таким образом, изучение сортимента сорговых культур позволяет рекомендовать для условий серых лесных почв юго-западной части Центрального региона ряд перспективных, высокоурожайных генотипов сорго селекции ВНИИ «Славянское поле»: Славянское приусадебное $\mathrm{F}_{1}$, Славянское поле $15 \mathrm{~F}_{1}-$ и гибриды сорго сахарного Порумбень 4 и Порумбень 5 селекции Института кукурузы и сорго «Порумбень» (Ре- 
Таблица 5

Влияние минерального питания на химический состав кормовой массы сорго сахарного, 2016 г.

\begin{tabular}{|l|c|c|c|c|c|}
\hline \multicolumn{1}{|c|}{ Вариант опыта, фаза развития } & \multicolumn{5}{|c|}{ Содержание в воздушн-сухом веществе, \% } \\
\cline { 2 - 6 } & $\mathrm{N}$ & $\mathrm{P}_{2} 0_{5}$ & $\mathrm{~K}_{2} 0$ & сырой протеин & сырая клетчатка \\
\hline $\begin{array}{l}\text { Кукуруза (без удобрений), восковая } \\
\text { спелость }\end{array}$ & 1,50 & 0,45 & 1,20 & 9,4 & 32,2 \\
\hline $\begin{array}{l}\text { Славянское приусадебное (без удо- } \\
\text { брений), восковая спелость }\end{array}$ & 1,63 & 0,43 & 1,12 & 10,2 & 31,4 \\
\hline $\begin{array}{l}\text { Кукуруза (борофоска + N } \\
\text { ная спелололоч- }\end{array}$ & 2,00 & 0,29 & 0,75 & 12,5 & 30,3 \\
\hline $\begin{array}{l}\text { Славянское приусадебное (борофо- } \\
\text { ска + } \mathrm{N}_{60} \text { ), молочная спелость }\end{array}$ & 1,75 & 0,32 & 0,70 & 10,9 & 28,5 \\
\hline
\end{tabular}

Химический состав и качество силоса

Таблица 6

\begin{tabular}{|c|c|c|c|c|c|c|c|c|c|c|c|}
\hline \multirow[b]{2}{*}{ Силос } & \multirow[b]{2}{*}{$\begin{array}{c}\text { Вода, } \\
\%\end{array}$} & \multirow[b]{2}{*}{$\begin{array}{c}\text { Зола, } \\
\%\end{array}$} & \multirow[b]{2}{*}{$\begin{array}{c}\text { Жир, } \\
\%\end{array}$} & \multirow[b]{2}{*}{$\begin{array}{c}\text { Клетчатка, } \\
\%\end{array}$} & \multirow[b]{2}{*}{$\mathrm{N}, \%$} & \multirow[b]{2}{*}{$P, \%$} & \multirow[b]{2}{*}{$\mathrm{pH}$} & \multicolumn{4}{|c|}{ Содержание органических кислот, \% } \\
\hline & & & & & & & & уксусная & масляная & молочная & $\begin{array}{l}\text { сумма } \\
\text { кислот }\end{array}$ \\
\hline $\begin{array}{l}\text { Сорго } \\
\text { сахарное }\end{array}$ & 81,0 & 5,9 & 1,62 & 23,9 & 1,3 & 0,44 & 3,80 & 0,415 & 0,061 & 0,437 & 1,212 \\
\hline Кукуруза & 81,5 & 4,9 & 1,57 & 24,8 & 1,0 & 0,25 & 3,85 & 0,405 & 0 & 0,497 & 0,902 \\
\hline $\begin{array}{l}\text { Сорго } \\
\text { сахарное + } \\
\text { кукуруза }\end{array}$ & 79,2 & 6,8 & 1,56 & 27,5 & 1,4 & 0,36 & 4,30 & 0,367 & 0 & 0,472 & 0,839 \\
\hline
\end{tabular}

спублика Молдова).

Изучаемые гибриды кормового сорго характеризовались не только различиями в побеговой структуре урожая, но и содержанием сахаров в соке стеблей и в целом химического состава кормовой массы. В наших опытах установлено, что внесение минеральных удобрений, особенно азотных, способствовало повышению содержания сырого протеина и незначительно влияло на долю в корме зольных элементов, клетчатки и БЭВ. При внесении азотных удобрений отмечено снижение концентрации водорастворимых сахаров, фосфора и калия (табл. 4, 5).

По результатам определения растворимых сахаров следует, что внесение минеральных удобрений заметно сказалось на концентрации сока стеблей изучаемых гибридов сорго. Так, на варианте применения борофоски отмечалось высокое содержание сахаров, особенно у сочностебельных растений сорго зернового Славянское поле $120 \mathrm{~F}_{1}(14,1 \%)$ и сорго-суданкового гибрида Славянское поле $15 \mathrm{~F}_{1}(14,5 \%)$.

При азотных подкормках проявилась общая тенденция снижения концентрации сахаров в соке стеблей гибридов сорго и кукурузы.

По сравнению с кукурузой отдельные генотипы кормового сорго содержали больше протеина, золы и по питательной ценности не уступали ей. Кормовая масса гибридов сорго незначительно различалась по содержанию основных питательных веществ (сырой протеин, сырая зола, сырая клетчатка, БЭВ). Результаты изучения химического состава зелёной массы (в пересчете на сухое вещество) показали, что содержание питательных веществ изменялось по фазам роста и развития и в зависимости от уровня минерального питания. В фазу стеблевания - выхода в трубку кормовая масса характеризовалась высоким содержанием сырого протеина $(14,4 \%)$, более низким - сырой клетчатки и БЭВ, особенно на вариантах, удобренных азотом. С возрастом растений как на контроле, так и с применением минеральных удобрений, содержание протеина в корме снижалось до 10,2-10,9 $\%$, а клетчатки - повышалось до $32 \%$.

Таким образом, внесение минеральных удобрений, особенно азотных, способствовало повышению качества и урожайности надземной массы, хорошему соотношению компонентов побеговой структуры.

С целью более полного представления о кормовой ценности надземной массы сорго сахарного нами была проведена заготовка силоса в фазе молочной спелости зерна в сравнении с 
кукурузой. Оценку качества силоса проводили по содержанию сухого вещества и питательных веществ, величина рН в соответствии с ГОСТ 55986-2014 (табл. 6).

Результаты химического состава силоса показали, что содержание питательных веществ выше в силосе у сорго сахарного: по содержанию сырого протеина, жира, зольных элементов, особенно фосфора - 0,44 \%, меньшее содержание сырой клетчатки - до $24 \%$. Концентрация молочной кислоты в сумме органических кислот соргового силоса составила $60,8 \%$, тогда как в силосе из кукурузы ее содержание находилось на уровне 55,1\%. Показатель рН заготовленных силосов был в пределах величины 3,8-3,85. Силосная масса кукурузы + сорго сахарного отвечала требованиям силоса I класса (ГОСТ 559862014). Качество силоса из сорго несколько ниже и соответствовало II классу. Он вполне пригоден для дойных коров, наиболее требовательных к диетическим свойствам силоса с приятным, ароматным, фруктовым запахом и хорошо сохраняет структуру корма.

\section{Выводы}

Полученные данные свидетельствуют, что уровни (фоны) минерального питания оказали существенное влияние на рост, развитие, продолжительность вегетационного периода, продуктивность, содержание питательных веществ и на устойчивость к абиотическим факторам сортимента сорговых культур. Внесение минеральных удобрений незначительно влияло на долю зольных элементов, сырой клетчатки и БЭВ, но способствовало повышению содержания сырого протеина и увеличению урожайности надземной массы, которую можно использовать для заготовки высококачественного зелёного корма, сенажа, силоса в агроклиматических условиях Брянской области. Результаты наших исследований позволяют рекомендовать ряд перспективных, высокоурожайных генотипов сорго селекции ВНИИ «Славянское поле» (Ростовская область): Славянское приусадебное $\mathrm{F}_{1}$, Славянское поле $15 \mathrm{~F}_{1}-$ и гибриды сорго сахарного Порумбень 4 и Порумбень 5 селекции Института кукурузы и сорго «Порумбень» (Республика Молдова) для возделывания на агросерых лесных почвах в региональном кормопроизводстве.

\section{Библиографический список:}

1. Алабушев, А.В. Происхождение сорго и развитие его селекции / А.В. Алабушев, Е.А. Шишова, А.Е. Романюкин, Г.М. Ермолина, С.И.
Горпиниченко // Политематический сетевой электронный научный журнал КубГАУ. - 2017. № 127. - С. 281-294.

2. Жужукин, В.И. Оценка комбинационной способности сортообразцов сахарного сорго / В.И. Жужукин, В.С. Горбунов, О.П. Кибальник, Д.С. Семин, А.Ю. Гаршин // Вестник российской сельскохозяйственной науки. - 2017.-№5. - С. 34-37.

3. Горпиниченко, С.И. Результаты селекции суданской травы и сорго-суданковых гибридов в ФГБНУ ВНИИЗК имени И.Г. Калиненко / С.И. Горпиниченко // Зерновое хозяйство России. - 2014. - Т.35.- №5. - С. 36 -40.

4. Малиновский, Б.Н. Содержание и накопление сахара в растениях сорго в зависимости от фазы / Б.Н. Малиновский, С.А. Нагорный // Кукуруза и сорго. - 2010. - №2. - С. 11-12.

5. Васин, В.Г. Влияние нормы высева на фотосинтетическую деятельность и продуктивность зернового сорго в условиях лесостепи Среднего Поволжья / В.Г. Васин, Н.В. Рухлевич, Н.А. Казутина // Вестник Ульяновской ГСХА. 2017. - №1(37). - С. 6-11.

6. Персикова, Т.Ф. Продуктивность гибрида сорго сахарного Славянское приусадебное в условиях северо-востока Беларуси / Т.Ф. Персикова, Е.А. Блохина // Вестник Белорусской ГСХА. - 2016. -№2. - С. 82-86.

7. Дронов, А.В. Агробиологическое обоснование интродукции сорговых культур в югозападный регион Нечерноземья России / Дронов А.В.: дисс... на соиск. уч. степ. д-ра с.-х. наук. - Брянск: Брянская ГСХА. - 2007. - 404 с.

8. Дронов, А.В. Научные идеи Н.И. Вавилова в интродукции культуры сорго в Нечерноземье России / А.В. Дронов, В.В. Дьяченко // Плодоводство и ягодоводство России. - 2012. - Т. 34. - №1. - С. 251-257.

9. Бельченко, С. А. Сорговые кормовые культуры в организации зелёного и сырьевого конвейеров в Брянской области / С. А. Бельченко, А. В. Дронов, В. Е. Ториков, И. Н. Белоус // Кормопроизводство. - 2016. - № 12. - С. 17-20.

10. Методические рекомендации по разработке производственной оценке качества кормов. - М.:ВАСХНИЛ, 1987. - 72 с.

11. Разумов, В. А. Массовый анализ кормов. Справочник / В.А. Разумов. - М.: Колос, 1982. -176 c.

12. Доспехов, Б. А. Методика полевого опыта (с основами статистической обработки результатов исследований) / Б.А. Доспехов. М.: Колос, 1985. - 352 с. 


\title{
PRODUCTIVITY OF FEED SORGO VARIETY DEPENDING ON MINERAL NUTRITION
}

\author{
Belchenko S.A., Dronov A.V., Shapovalov V.F. \\ FSBEI HE Bryansk SAU \\ 243365, Bryansk region, Vygonichsky district, Kokino v., Sovetskaya st., $2 a$ \\ Tel / Fax: +7 (48341) 24-721; \\ e-mail: cit@bgsha.com
}

Key words: feed sorghum, hybrids, mineral nutrition, productivity, nutrients.

As a result of field experiments on agroforest forest soils of the Bryansk region, we found that mineral fertilizers (nitrofoska, borofoska, ammonium nitrate) had a significant impact on the growth, development and productivity of sorghum crops, nutrient content and resistance to abiotic factors. The genotypes of sugar sorghum F1 Porumben 4 and Porumben 5 of the selection of the Institute of Corn and Sorghum (Republic of Moldova) were most productive: 14.4-15.2 $t$ / ha of dry matter. The yield of sorghum-sudangrass hybrids of the selection of All-Russian Research Institute of sorghum and soya "Slavianskoe Pole" was 8.4-9.8 $\mathrm{t}$ / ha of dry matter in case of single-cut use (silage variant). The structure of the sugar sorghum yield (\%): on average, the share of leaves was 51.3, the stems - 41.7, the panicle - 7.0, the structure of dry weight of the sorghum- sudangrass hybrids: 42.1-56.2\%, 42. 4-50.0\%, panicle - 6.4-7.9\%, respectively. High sugar content was noted on the borofosks variant, especially in plants of the chylocaulous sorghum-sudangrass hybrid Slavyanskoe Pole 15 F1 (14.5\%). In case of nitrogen fertilizing, a general tendency was observed to reduce the concentration of sugars in the stem juice, as well as phosphorus and potassium of the studied hybrids of sorghum and corn. The concentration of nutrients changed in different phases of growth and development depending on the mineral nutrition. The forage mass was characterized by a high content of crude protein (14.4\%), at the stem-extention phase-entering the tube, a lower one - of crude fiber and nitrogen-free extractive substances, especially in variants fertilized with nitrogen. At the milk-wax stage of ripeness, the content of crude protein in feeds decreased to 10.2-10.9\%, and the crude fiber increased to 32\%. Application of mineral fertilizers had little effect on the proportion of ash elements, crude fiber and nitrogen-free extractive substances, but contributed to an increase of crude protein content and yield of the above-ground mass which can be used for harvesting high-quality green forage, haylage, silage.

Bibliography

1. The origin of sorghum and the development of its selection [Electronic resource] / A.V. Alabushev, E.A. Shishova, A.E. Romanyukin, G.M. Ermolina, S.I. Gorpinichenko // Polythematic network electronic scientific journal KubSAU. - 2017. - No. 127. - P. 281-294.

2. Evaluation of combinability of varieties of sugar sorghum / V.I. Zhuzhukin, V.S. Gorbunov, O.P. Kibalnik, D.S. Semin, A.Yu. Garshin // Vestnik of Russian Agricultural Science. - 2017.-No5. - P. 34-37.

3. Gorpinichenko, S.I. Results of selection of Sudan grass and sorghum-sudangrass hybrids in FSBSI All-Russian Scientific Research Institute of Cereal Crops named after I.G. Kalinenko /S.I. Gropinichenko // Grain economy of Russia. - 2014. - Volume 35, №5. - P. 36 -40.

4. Malinovsky, B.N. Content and accumulation of sugar in sorghum plants depending on the phase / B.N. Malinovsky, S.A. Nagornyy // Corn and sorghum. - 2010. - №2. - P. 11-12.

5. Vasin, V.G. Influence of seed amount on photosynthetic activity and productivity of grain sorghum in the conditions of the forest-steppe of the Middle Volga region / V.G. Vasin, N.V. Rukhlevich, N.A. Kazutina //Vestnik of Ulyanovsk State Agricultural Academy. - 2017. - No. 1 (37). - P. 6-11.

6. Persikova, T.F. Productivity of sugar sorghum of Slavyanskoye Priusadebnoe hybrid in the conditions of the northeast of Belarus / T.F. Persikova, E.A. Blokhina // Vestnik of Belarusian State Agricultural Academy. - 2016.-No2. - P. 82-86.

7. Dronov, A.V. Agrobiological substantiation of introduction of sorghum crops in the southwestern region of the Non-Black Soil Region of Russia: dissertation of Doctor of Agriculture / A.V. Dronov .- Bryansk: Bryansk State Agricultural Academy. - 2007. - $404 p$.

8. Dronov, A.V. Scientific ideas of N.I. Vavilov concerning introduction of sorghum culture in the Non-Black Soil Region of Russia / A.V. Dronov, V.V. Dyachenko // Fruit growing and grapes cultivation of Russia. - 2012. - Volume 34, №1. - P. 251-257.

9. Sorghum feed crops in the organization of green and raw conveyors in Bryansk region / S.A. Belchenko, A.V. Dronov, V.E. Torikov, I.N. Belous // Feed production. - 2016. - No. 12. - P. 17-20.

10. Methodical recommendations on the development of an industrial assessment of feed quality. - M.: All-Union Academy of Agriculture named after V.I. Lenin, 1987. - $72 p$.

11. Razumov, V. A. Mass analysis of feeds: reference book/V.A. Razumov. - Moscow: Kolos, 1982. - $176 p$

12. Dospekhov, B.A. Method of field experiment (with the basics of statistical processing of research results) / B.A. Dospekhov. - Moscow: Kolos, 1985. $352 p$. 